\title{
Exchange rate policy and macroeconomic adjustment
}

Geng Xiao

\section{China's exchange rate policy and what it means for the dollar}

The debate over the exchange rate between the renminbi (RMB) and the US dollar is usually framed in terms of global imbalances: excessive US consumption beyond its savings on the one hand and excessive Chinese production and savings beyond its own spending on the other. This quickly leads to the view that the United States should export and save more and China should import and spend more. The debate centres on how to achieve this rebalancing. The focus in the West is on short-term appreciation of the renminbi, while the emphasis in China is on longer-term structural and institutional reform (Xiao 2008). ${ }^{1}$

Leaders in the United States would like the renminbi to appreciate significantly and quickly to encourage an expansion of US exports and employment. Chinese leaders, however, regard the pressure to revalue the renminbi and various protectionist trade policies from the West as unfair, and believe they threaten China's development. ${ }^{2}$ What accounts for this considerable gap between the views of China and the West? What is the economic rationale for China's insistence on a stable renminbi?

The argument for a sustained appreciation of the renminbi is rooted not only in short-term concerns about China's large current account surplus, but in longerterm trends of China's economic fundamentals, including high growth, rapid urbanisation and industrialisation, low national debt and low fiscal deficits. These trends are the result of three decades of reform in China that have opened the country to trade with the rest of the world and led to strong productivity gains. Based on the experience of other fast-growing industrialising economies, these forces will increase Chinese wages, the value of the renminbi and China's price level_-over time.

1 Some of the key results are summarised and restated in this chapter.

2 On 30 November 2009, in his meeting with European leaders, Chinese Premier, Wen Jiabao, said some countries on the one hand demanded renminbi appreciation and on the other hand adopted various trade protection meaures. 


\section{China's stance}

China views its renminbi peg with the US dollar as a crucial link for its trade and investment flows with US and world markets. China is concerned that a premature end to this nominal link with the dollar would bring about financial instabilities such as speculative capital inflows, associated asset bubbles and short-term nominal shocks to employment and business in the external sector.

China has not forgotten how the large appreciation of the Japanese yen brought about by the 1985 Plaza Accord created massive asset bubbles that burst in 1989, creating a two-decade-long period of sustained deflation without eliminating Japan's trade surplus.

China is also wary of how currency appreciation might encourage destabilising capital inflows. From 2005 to 2008, the renminbi appreciated steadily against the United States dollar by over 5 per cent a year and China's stock-market index increased from about 1500 to 6000 before falling to 2000 because of large speculative capital inflows especially from Hong Kong. If China were to use renminbi appreciation to reach a balance in trade and to stop speculative capital inflows, the renminbi could overshoot its equilibrium level, leading to bubbles and deflation.

Another reason for not having predictable renminbi appreciation relates to China's outward investment. For a country with a large net surplus savings and trade surplus, a well-functioning financial system should support orderly private or non-state capital outflows of the same order of magnitude as the trade surplus. Private firms and financial institutions would, however, be reluctant to buy dollar assets if they were likely to continually depreciate in terms of the renminbi. Because fear of dollar depreciation - and the near-zero short-term interest rates in the United States - reduces outward investment by privatesector investors, the People's Bank of China (PBOC) has to finance virtually all of China's trade surplus by building up official exchange reserves, making its monetary control difficult. ${ }^{3}$

In any case, it is not clear that nominal renminbi appreciation is necessary. The real exchange rate between the renminbi and the US dollar should be selfadjusting. This is because the change in China's price level relative to that in the United States (the 'real exchange rate') is technically the sum of renminbi appreciation against the dollar and China's extra inflation above US inflation. This real exchange rate is determined largely by China's productivity growth. If China appreciates its currency in excess of its productivity gains, it will

\footnotetext{
3 See a series of articles by Ronald McKinnon about the exchange-rate policy in Japan and Chinaparticularly McKinnon et al. (2009).
} 
experience deflation. If, however, China refuses nominal appreciation against its productivity gains, the country will experience some structural inflation related to the increase of wages and prices in the non-tradable sector, which will keep the real exchange rate compatible with its productivity changes. If China experiences inflation higher than its productivity gains, the renminbi will face depreciation pressure.

Indeed, if China makes the mistake of continually appreciating the renminbi against the dollar - ostensibly to reflect its higher productivity growth in manufacturing - then wage growth could well slow by roughly the amount of the anticipated exchange appreciation. Manufacturing firms would risk bankruptcy if they raised wages in the face of an ever-higher renminbi. Indeed, in Japan's very high growth phase in the 1950s and 1960s, when the yen was fixed at 360 to the dollar, Japanese wages grew very rapidly - at about the same pace as domestic productivity growth in manufacturing. Then, when Japan was forced by the US government to appreciate in the 1970s and afterwards, wage growth slumped to virtually zero and remains at zero today. ${ }^{4}$ China does not want to repeat Japan's experience of deflationary stagnation by allowing excessive renminbi appreciation.

It should also be noted that recent research by Hong Qiao (2007) has shown that currency appreciation has an ambiguous impact on the net trade balance. Qiao's (2007) research is clearly consistent with Japan's experiences and supports China's current exchange-rate policy.

When it comes to rebalancing, what really matters is the real exchange rate: the relative price levels between economies in international currency, which determine the relative costs of production, exports and imports of trading partners. Hence, if China pegs the renminbi to the dollar, it can still achieve a rapid increase in its real exchange rate against the United States by having an inflation rate 5 percentage points higher than that of the United States. Many formerly fast-growing industrialising economies - such as Japan, South Korea, Taiwan and Hong Kong - kept inflation about 5-8 per cent during their fastgrowth phases as a way to make nominal wages and general price levels converge towards global standards.

Hence, both inflation and nominal appreciation can adjust the real exchange rate. The Chinese approach to exchange-rate stability thus far has focused on inflation first and appreciation second, which makes the longer-term objectives of creating employment, productivity gains, wage growth and price liberalisation the priorities rather than addressing trade imbalances through adjustments for exchange-rate change.

4 See detailed analysis in McKinnon (2006). 


\section{Policy alternatives}

Given the fact that China is cautious about using large nominal appreciation to rebalance the Chinese and global economies - at least for the time being - it is important to consider some alternative policy options. A widely held view in China is that the rebalancing should focus on reducing the net savings surplus by shifting disposable income to households, paying corporate dividends, increasing governments' fiscal spending, and so on-and not simply on adjusting the exchange rate.

China is well known for its high savings rate, which reached about 55 per cent of gross domestic product (GDP), with a current account surplus of about 10 per cent of GDP, during 2007-08. One of the key sources of China's high national savings rate is its state-owned enterprises (SOEs), as corporate savings contribute about half of China's national savings (Prasad 2009). Historically, these large SOEs could not pay high salaries or wages to their employees due to tight control by the government. They did not distribute dividends. Even after they were reformed into a modern corporate format in the 1990s, the primary focus was on reducing losses, not sharing dividends. They also did not generate private purchasing power when the prices of their shares increased, which created huge capital gains with, as it happens, only small wealth effects on consumption. The high savings of SOEs are prone to investment in sectors with tendencies to overcapacity. Hence, privatisation and deregulation are necessary to reduce savings and inefficient investment by the large SOEs. ${ }^{5}$

While China clearly must increase its current consumption, consumption is ultimately limited by income. China has a long way to go in raising the wages and productivity of its workforce. Right now, household income accounts for only 35 per cent of national income. The low disdposable income is especially acute for migrant workers, who do not receive high-quality education in rural villages. Their wages were stagnant at a level of about US\$120-200 a month for the first several decades of reform due to steady high underemployment for unskilled labour.

Chinese savings are also high because the average Chinese household is faced with a very high return on investment, such as in residential property. In one of our studies (Sun et al. 2009) of the comparative long-term return on capital for China, Japan and the United States, we found that China's return on capital is about 20 per cent, compared with about 10 per cent for Japan and 5 per cent for the United States in the past three decades. Moreover, Chinese households save to meet very high future expenditures, such as college education for their single child and medical and retirement expenditures.

5 For more on China's SOEs, see the discussion by Xiao et al. (2009). 


\section{Addressing the West's concerns}

Chinese and foreign observers alike have expressed concerns about inefficient investment in China's export-manufacturing sector and in some local government-sponsored projects. As a result, China's central government has recently tightened monitoring and control of all new projects, especially those likely to lead to overcapacity. The Chinese authorities have not, however, changed their overall stimulus policy and continue to focus on generating more efficient investment, employment and imports so as to contribute positively to global rebalancing and global recovery.

For those who worry about China's US $\$ 2.2$ trillion foreign exchange reserves, it is worth looking at a case that illustrates China's need for foreign exchange. The number of self-financed Chinese students studying abroad increased from 102 247 in 2002 to 161600 in 2008, which is a compound rate of about 8 per cent a year. If we assume the number of such students will increase 8 per cent a year for the next 10 years, the number of students studying abroad will reach 348 882 by 2018 . If each outgoing student spends four years overseas, with US\$60 000 in expenditure per annum for tuition, living expenses and travel, the total accumulated expenditure for those Chinese students going abroad will reach US $\$ 606.8$ billion - amounting to about 30 per cent of China's current foreign exchange reserves. It is no secret that even high and middle-income Chinese parents need to save for many years or decades to pay for their children's expensive overseas education.

\section{Price distortions and global rebalancing}

One of the key factors driving the global imbalances has been cheap money, which, together with weak regulation of high-risk investment, led to property and stock-market bubbles in the United States and other economies. The bubbles brought temporary capital gains that reduced Americans' savings and increased their consumption to levels beyond their sustainable income. This is well known now; but what has been overlooked in the public discussion is that this same cheap money also flowed into China through foreign direct investment (FDI) and other capital flows. Cheap foreign money, combined with cheap Chinese land, energy and natural resources, has led to huge overcapacity in China's manufacturing sector, driving down the prices of made-in-China products.

The United States' current zero-interest-rate policy might be necessary for the US economy now, but it is likely to create a carry trade as a by-product that is, where investors borrow currencies with low interest rates and invest 
in currencies with high interest rates to make profits when the interest rate differential is larger than the anticipated exchange rate change. This brings capital flows into China in anticipation of higher investment returns compared with the United States. If managed well, China can combine this foreign capital and its own savings to improve the efficiency of its investment, so as to allow higher levels of domestic investment for future domestic consumption. This would certainly help global rebalancing.

Rising Chinese household income and large official reserves mean that there will be rising demand for diversification by Chinese investors into foreign assets. Over time, the amount of cross-border capital flows could be much larger than the amount of trade flows. To facilitate these future cross-border capital flows, it would be helpful for China to maintain a stable exchange rate and large foreign exchange reserves - both of which are critical in reducing the Chinese and foreign investors' uncertainty that would result from a volatile exchange rate. Having a stable exchange rate to facilitate cross-border investment is also important for the large number of US multinational corporations with extensive and growing investments in China that generate high value-added complementary jobs in the United States.

\section{The future for China and the dollar}

The biggest challenge for Chinese policymakers now is how to deal with the property and stock-market bubbles being formed by cheap money in China and around the world. As asset prices and the consumer price index (CPI) rise, it is important for China to raise its interest rate - as India has done very successfully - to keep the real interest rate at a stable and positive level. A higher interest rate would attract greater capital inflows. It is therefore necessary for China to improve its capital-control mechanisms, to allow orderly crossborder capital flows for more efficient investments with higher returns both domestically and internationally, while limiting the speculative flow of capital and the inefficient and low-return investments.

So what does China's policy stance mean for the dollar? There are some clear implications.

Given the institutional and structural constraints in China, it does not seem likely that nominal renminbi appreciation will become a key policy variable in rebalancing China and the global economy in the near future. This means it will be difficult for the United States to pursue a weak-dollar policy. Without depreciation against the renminbi, any further depreciation of the dollar against the euro and yen would do little to help global rebalancing - and could instead cause shocks to the European and Japanese economies. 
Given the huge potential for cross-border investment and debt financing between the United States and China, a stable renminbi-dollar exchange rate seems to fit both countries' long-term national interest. If the United States and China can cooperate effectively in maintaining the stability of the exchange rate and orderly cross-border flows of capital, there is little reason to believe the dollar-based international currency system will collapse in the foreseeable future.

In the longer term - certainly after 2020 and perhaps during 2025-35-the renminbi is likely to become an international currency when it becomes fully convertible and the Chinese economy completes its structural and institutional transformation into a fully modernised market economy with a more democratic political system. By that time, the integration of the US, European, Japanese and Chinese economies will be so deep that the dollar, euro, yen and renminbi are likely to become leading reserve currencies of the world, with fully floating exchange rates.

Rebalancing the world economy can be accomplished without revaluing the renminbi. For this to happen without major dislocations, however, structural and institutional reforms must occur both in China and in the United States. Higher inflation in China and deflation or lower inflation in the United States can bring about the needed adjustment in real, rather than nominal, exchange rates. This implies a stronger dollar, but also requires de-leveraging in the United States, including reduction of US fiscal deficits.

\section{Challenges in the next two decades}

During the next 20 years of reform and development, the key macroeconomic challenge is to determine how to manage the exchange rate, interest rate and inflation rate in order to facilitate sustainable, stable, efficient and harmonious growth of China's real economy in the context of a world economy in which the weight of the Western economies will shrink relative to the emerging market economies.

To appreciate the extent of this challenge, it is essential to recognise that China's high growth in the past 30 years is a story largely of rapid productivity growth and catching up. The productivity story is likely to continue for the next two decades if China continues its market-oriented reform and its trend of rapid industrialisation and urbanisation. As a result, China's non-tradable goods prices - such as wages for unskilled labour and property prices - are likely to continue to rise (see the chapter in this volume by Ross Garnaut), relative to the prices of tradable goods, which are set by global markets. 
In the next two decades, rising non-tradable goods prices in China will lead to a gradual but steady convergence of China's price levels towards those in Hong Kong and the United States, through structural inflation or structural renminbi appreciation - or both. It is essential for China's policymakers and Chinese people to tolerate the structural inflation and/or currency appreciation associated with this productivity catch-up.

More importantly, since inflation and currency appreciation can cause distortions, shocks and income redistribution, it is necessary for policymakers to use appropriate policy mixes to mitigate potential dislocation that might be created in the adjustment process.

For example, when structural inflation emerges, it will be critical to raise nominal interest rates so as to avoid asset bubbles that are caused by negative real interest rates as well as to protect the value of bank deposits held by the lowincome households who cannot afford to invest or speculate in property markets in order to hedge against the structural inflation. Since 1991, China's urban residential real estate prices have grown on average about 9 per cent a year, but the mortgage rate is only about 5 per cent and the one-year fixed-deposit rate is only about 2 per cent. The structural inflation in property and low mortgage and deposit rates implies a very serious problem of negative real interest rates in terms of investing in property. This is the root of China's property bubbles and the associated huge income redistribution from depositors (usually the poor) to mortgage holders (usually the rich).

If China cannot maintain a positive real interest rate, its boom and bust cycles in the property sector are likely to continue, leading to serious inefficiency in investment as well as social instability. On the other hand, if China does raise interest rates to a level higher than its structural inflation, it then needs adequate capital control to deal with speculative capital inflows.

The importance of keeping the real interest rate positive cannot be overemphasised for China in the next two decades, as China's key challenge in macroeconomic adjustment is to improve its investment and consumption efficiency so that it can absorb more of its current account surplus. Otherwise, China will face serious international trade protection pressure.

On the other hand, this chapter shows that it is not necessary for China to rely only on nominal exchange rate flexibility to facilitate its rising price level if it can instead tolerate higher structural inflation and the associated real appreciation. In fact, it is much easier for China to implement a flexible exchange rate regime when it allows reasonable structural inflation. With inflation, there will be potential for the currency to depreciate when inflation runs beyond productivity growth. So, a mixture of inflation and nominal appreciation could 
create a regime in which the market exchange rates could go up or downreducing the incentive for massive speculative holdings of the renminbi, which has become one of the key drivers of China's foreign exchange reserve bubble.

It should also be pointed out that when China pegs its renminbi to the US dollar, it should not worry too much about runaway inflation since the peg has the stabilisation function. If the inflation rate goes beyond China's underlying productivity growth, the market will expect the renminbi to depreciate, which will lead to capital outflows and the tightening of money supply. Given China's huge foreign exchange reserves, it is easy for China to defend its peg and avoid runaway inflation.

As soon as China starts to tolerate reasonable structural inflation and the associated real appreciation, the pressure for nominal appreciation will be reduced.

This chapter has also highlighted the fact that the exchange rate is a price not just for trade but for assets. In fact, the volume of the asset markets is much bigger than that of trade. Maintaining stable exchange rates for facilitating stable and efficient cross-border capital flows could be more important than using the exchange rate to balance trade. It could be more productive to use trade policies such as reducing the transaction costs for imports to balance China's trade.

\section{References}

McKinnon, R. 2006, 'China's exchange rate trap: Japan redux?', American Economic Review, vol. 6, no. 2, pp. 427-31.

McKinnon, R. Lee, B. and Wang, Y. D. 2009, The global credit crisis and China's exchange rate, Stanford Center for International Development Working Paper no. 391, Stanford University, Calif.

Prasad, E. 2009, 'Rebalancing growth in Asia', Finance \& Development, vol. 46, no. 4, pp. 19-22.

Qiao, H. 2007, 'Exchange rates and trade balances under the dollar standard', Journal of Policy Modeling, vol. 29, no. 5, pp. 765-82.

Sun, W., Yang, X. and Xiao, G. 2009, Investment rate and FDI: a comparative analysis of return to capital among China, US and Japan, Paper presented at the joint symposium of US-China Advanced Technology Trade and Industrial Development, Beijing, 23-24 October. 
Xiao, G. 2008, 'China's exchange rate and monetary policies: structural and institutional constraints and reform options', Asian Economic Papers, vol. 7, no. 3, pp. 31-49.

Xiao, G., Yang, X. and Janus, A. 2009, 'State-owned enterprises in China: reform dynamics and impacts', in R. Garnaut, L. Song and W. T. Woo (eds), China's New Place in a World in Crisis: Economic, geopolitical and environmental dimensions, ANU E Press, Canberra, pp. 155-78.

\section{Acknowledgments}

This chapter consists of two sections. Section one is a reprint of an article by the author published on 13 January 2010 at 'What Matters' web forum hosted by the McKinsey Quarterly (<http://whatmatters.mckinseydigital.com/currencies/ china-s-exchange-rate-policy-and-what-it-means-for-the-dollar $>$ ). Section two includes additional comments prepared specially for this chapter. The author is grateful to the McKinsey Quarterly for permission to include the previously published contents in this chapter. The author would also like to thank Ronald McKinnon, Andrew Sheng, Pieter Bottelier, Wing Thye Woo, Jeffrey Sachs, Barry Bosworth, Harry Broadman, David Dollar, David Loevinger, David Meale, David Skilling, Jonathan Woetzel, Kenneth Lieberthal, Cheng Li, Xingdong Chen, Chunlai Chen, Min Zhu, Qiren Zhou and Hong Liang for helpful comments and discussions on this work. Jonathan Delikat and Will Hobbs provided excellent research assistance. 